\title{
Contrasting the Governance of Supply Chains with and without Geographical Indications: Complementarity between Levels
}

\author{
Marta Fernández-Barcala \\ School of Economics and Business, University of Oviedo, Spain \\ Manuel González-Díaz \\ School of Economics and Business, University of Oviedo, Spain \\ Emmanuel Raynaud \\ UMR SADAPT, AgroParisTech, INRA, Université Paris Saclay, France
}

\begin{abstract}
ABOUT THE AUTHORS
Marta Fernández-Barcala is Associate Professor of Strategy and Operations Management at the University of Oviedo, Spain. Her research interests are in the areas of organization economics and public-private-partnerships (PPP). She has published in a number of international journals and she is currently working on the study of supply chains governance at Geographical Indications.
\end{abstract}

Manuel González-Díaz is Professor of Business Economics at the University of Oviedo in Spain and member of the board of directors of the International Society of Franchising (ISoF). His main research interests are the inter-organizational relationships, focusing on their governance mechanisms and performance. He has published numerous papers and book chapters about procurement and subcontracting, particularly in transportation and construction industries. He has also extensively researched on franchising and other business networking. He also works as occasional consultant for companies and institutions on governance and organizational issues.

Emmanuel Raynaud is a research fellow at INRA (department SAD) the leading French research institute dedicated to the agricultural sector. He is also the head of the pluridisciplinary research unit SADAPT. He has work extensively on various topics such as the governance of franchised chains, vertical coordination in agribusiness sectors and products' quality, the dynamics of institutions framing economic transactions. He is currently working on the procurement strategies and governance choice in institutional catering.

\section{CORRESPONDING AUTHOR}

Marta Fernández-Barcala can be contacted at: mbarcala@uniovi.es 


\begin{abstract}
Purpose: The aim of this paper is to explain the organizational changes along supply chains when a geographical brand, i.e., a place name that has value for commercial purposes, becomes a Geographical Indication (GI).

Design/methodology/approach: Employing a case study research design, this paper compares GI vs. non-GI supply chains in the EU and describes the organizational changes that occur in supply chains when a GI is adopted.

Findings: When a GI is adopted, (1) an additional "public" level of governance is added along the supply chain that forces it to (2) reallocate and specialize quality controls between the public and private levels of governance to avoid redundancies and to (3) adopt more market-oriented mechanisms of governance in dyadic relationships. The paper argues that these changes occur because the private and public levels of governance complement one another.
\end{abstract}

Research limitations/implications: More aspects of supply chain management (the power balance or relationship stability) and a more systematic longitudinal analysis using supply chains in various agrifood industries should be considered to generalize the conclusions. An econometric analysis formally testing the main conclusions (propositions) is also required.

Practical implications: The needed changes to successfully adopt a GI are identified, and an explanatory map of these changes is offered.

Originality/value: The structural governance tensions created by the use of commonpool resources within supply chains are explored. It is hypothesized, first, that when a "common-pool resource," namely a geographical name, is used in a supply chain, some type of public level of governance that promotes cooperation is required to preserve its value. Second, this public level of governance complements the dyadic mechanisms of governance, requiring the specialization and reallocation of quality controls, and the move toward more market-oriented transactions.

Key words: Geographical Indications; supply chain; mechanisms of governance; free riding; quality; complements.

Article Classification: Case study 


\section{ACKNOWLEDGEMENTS}

The authors would like to express their gratefulness to the editor and the anonymous referees for their constructive and helpful comments that significantly improve the paper. The authors also gratefully acknowledge the financial support provided by the Spanish Ministry of Economy and Competitiveness (Project ECO2013-40407-R). 


\section{INTRODUCTION}

A product's quality, reputation and other characteristics can be affected by where it comes from. Geographical Indications (GIs) developed in the EU agrifood sector are place names or words associated with a geographical place that are used to identify products that come from that territory (for example, "Roquefort" or "Parma") because they have certain differential characteristics that have become well known and valued by consumers. From an economic point of view, place names can be treated as common-pool resources (Ostrom, 2010) because they are public trademarks and consequently can be freely used. The EU has regulated their use through legal structures known as Geographical Indications. From an organizational point of view, they represent collaborations among agribusiness producers in supply chains (Ménard and Klein, 2004) and governmental administrations. They contribute to designing and governing supply chain activities and to establishing and maintaining supply chain relationships, which are the critical activities for collaboration in the Supply Chain Management - hereafter SCM - literature (Matopoulos et al., 2007). Finally, from a political perspective, GIs are the main pillar of the European "quality policy" for the agrifood sector (Becker, 2009) and are a growing phenomenon in the market for agricultural products and foodstuffs. Thus, there were more than 1,300 registered GIs in the EU at the end of 2016 (see FIGURE 1).

This institutional solution to manage these "common-pool resource" brands has attracted the attention of scholars in a variety of fields. Marketing scholars have focused on the demand side, and they consider GIs to be a valuable signal of quality, for which consumers are typically willing to pay a price premium (Bouamra-Mechemache and Chaaban, 2010; Costanigro et al., 2010; Fernández-Barcala and González-Díaz, 2006; Loureiro and McCluskey, 2000). From the supply perspective, other scholars treat GIs as a governance mechanism that modifies incentives and vertical coordination in the supply chain, thus 
affecting the quality of the end products (Ménard and Klein, 2004; Ménard and Valceschini, 2005; Ponte and Gibbon, 2005). These scholars observe that demand for high-quality agrifood products generally trends toward tight vertical control of the supply chain and suggest that GIs improve coordination among small producers. This finding is consistent with the more general conclusion of the literature on governance and SCM that more formal governance mechanisms enhance coordination and control (Fearne, 1998; Pilbeam et al., 2012).

However, to the best of our knowledge, scholars have not explained the changes (and the reasons behind these changes) that occur in supply chain governance when a GI is implemented. In other words, why are the supply chains of GI products governed differently from the supply chains of non-GI products? This research question complements the theoretical developments of Mena et al. (2013) regarding the dynamics of SCM. These authors theorize about how the power balance, structure, interdependence and relationship stability change as multi-tier supply chains move from an "open chain" (where a buyer has no direct connection to its suppliers' suppliers) to a "closed chain" (where such a link has been formally established), but they do not consider the influence of institutional changes as with the constitution of a GI. Relatedly, Raynaud et al. (2005) contrast different quality enforcement modes - self-enforcement (reputational capital) vs. third-party enforcement (public certification) - in chains with and without GIs. The authors argue that more vertically integrated transactions are justified for private trademarks because the owners put their reputational capital at risk and want direct control to avoid free riding. Although true, this explanation is incomplete because it does not consider that both quality enforcement modes can (and often do) coexist within a GI (i.e., producers use both private trademarks and geographical branding, which is called co-branding (Landon and Smith, 1998)). The question then does not involve choosing between self-enforcement and third-party enforcement but instead involves explaining why and how these two modes coexist and overlap in GIs. 
The aim of this paper is to compare supply chains operating under GIs (i.e., with a value-adding place name plus private trademarks) with supply chains that involve only private trademarks to identify and explain governance changes in supply chains related to the introduction of a GI. It is essential to understand how and why GI-driven changes help to achieve tight coordination and overcome the difficulties induced by using place names as commercial brands. According to Ostrom (2010), these difficulties include free riding and poor incentives to invest in protecting and enhancing assets (reputation and brand awareness in the case of GI).

A case analysis is performed because of the lack of previous theoretical studies and because this research aims for theoretical development. In particular, Blome et al. (2013, p. 75) call for more qualitative research to determine how and when to implement complementary mechanisms of governance (i.e., ambidextrous governance) in SCM. Furthermore, enhancing theory building is one of the main challenges of supply chain scholarship as a discipline (Ketchen and Hult, 2011). The final idea is then to infer theoretical propositions or hypotheses about how the organization of supply chains changes when GIs are implemented and to reveal some insights for scholars and practitioners.

This study relies on Transaction Cost Economics - hereafter TCE (Coase, 1937; Heide, 1994; Masten, 1996; Williamson, 1985, 2008) - because it provides a natural and relevant framework to describe and explain the choice of organizational arrangements within supply chains (Hobbs, 1996, Hobbs and Young, 2000, Williamson, 2008). This theoretical approach, mixing Institutional Economics and TCE, has recently been applied by Dorobantu et al. (2017) to explain how firms are organized and governed to face weak institutions using nonmarket business strategies. Relatedly, this study aims to examine the governance implications of two stylized facts derived from the analysis of GIs: (i) the quality of the final product is the result of decisions made at various steps/nodes on the supply chain, suggesting 
strong interdependence among different links/transactions; and (ii) the different levels of governance (public and private) overlap [1].

This paper's contribution to the SCM and TCE literature is threefold. First, this paper explains why the introduction of an additional level of governance is required so that supply chains can take advantage of the use of valuable common-pool resources (i.e., geographical brands). These streams of literature have not yet explored the structural governance tensions and dynamics created in such a setting. This paper contributes to reducing this gap by identifying the needed changes and by extending the study of supply chain dynamics (Mena et $a l ., 2013)$ with the introduction of institutional arrangements that improve cooperation. In particular, it is observed that the introduction of GIs leads to quality control specialization and the use of more market-oriented mechanisms of governance at all dyads.

Second, this paper also shows that there are complementarities between the public and private levels of governance in GIs' supply chains, which extends the range of complementarities observed in SCM (Blome et al., 2013; Tachizawa and Wong, 2015) [2]. Publicly regulated mechanisms of governance such as GIs complement each privately chosen governance mechanism at all dyads, and they solve problems together that could not have been solved separately. The private level alone cannot overcome the free riding problem due to the common-pool resource nature of the GI brand, and the public level alone does not provide sufficient incentives to invest in and improve product quality in the long run. This finding also sheds light on the TCE discussion about how different mechanisms of governance work together, aspects to which both the business and economic literatures have paid extensive attention (Ennen and Richter, 2010; Lafontaine and Slade, 2013, p. 10011004).

Finally, this complementarity between levels shows that the unit of analysis in studies of SCM should be the supply chain as a network instead of dyads (Carter et al., 2015; Choi 
and Kim, 2008; Matopoulos et al., 2007; Mena et al., 2013; Pilbeam et al., 2012; Wever et $a l ., 2012$ ). If this paper had analyzed only dyads or triads, the complementarities between the levels of governance in GIs would not have been observed. This difficulty of observing complementarities when a complex system is excessively simplified is a constant in the literature (Ennen and Richter, 2010). The question of the unit of analysis is also relevant with regard to TCE (Williamson, 1985, 2008). This framework focuses on the governance decision for individual transactions, the implicit assumption being that transactions can be considered as independent from one another (Mena et al., 2013). If interdependencies among bilateral transactions are introduced, for example because of the progressive construction of quality all along the chain, it might trigger a revision of the standard TCE framework in order to explicitly introduce some system considerations.

The remainder of this paper is organized as follows. First, we describe GIs' institutional structure and provide some insights regarding their quantitative significance. Second, we explain our methodology and the case selection. Third, we compare cases and emphasize the similarities and dissimilarities between GI and non-GI supply chains, providing theoretical propositions about the governance of supply chains. Finally, we conclude by highlighting the conceptual contribution of this research, explaining its limitations and discussing some of its managerial implications for firms involved in GI supply chains.

\section{EU GEOGRAPHICAL INDICATIONS: INSTITUTIONAL ORIGIN AND MAGNITUDE}

GIs refer to the EU legal form for "identification and, where appropriate, protection of names and terms that, in particular, indicate or describe agricultural products with valueadding characteristics" (Regulation (EU) No 1151/2012). There are two main slightly different legal forms of GIs: a) Protected Designation of Origin (PDO), i.e., the name of a product that is produced, processed and prepared in a determined geographical area using 
recognized know-how; and b) Protected Geographical Indicator (PGI), a term that denotes that agricultural products and foods are closely linked to the geographical area in which they are produced, processed or prepared. Firms involved in a GI supply chain must be organized in a collective organization (for instance, an association of firms, a syndicate) to apply for registration. This requirement highlights the collective nature of a GI. European regulations on GIs resemble trademark registrations that protect the property rights of brands; however, in contrast to a trademark, a GI brand takes on a place name (e.g., Parma Ham) that can be commonly or publicly used - a particularity with which GI regulations must grapple (see Bureau and Valceschini (2003), Gragnani (2013) and the previously mentioned Regulation for a fuller description of the GI system).

Although not all GIs have the same outcomes or the same success rates over the long term, GIs are a prolific phenomenon in the EU and an important part of the agribusiness sector in particular. The GI system is also an important topic in the Transatlantic Trade and Investment Partnership (TTIP) negotiations because its protection is one of the key objectives of the Commission [3]. FIGURE 1 shows the evolution of the number of registered GIs for agricultural farm products and foodstuffs in the EU from 1996 to 2016. TABLE 1 displays the wholesale value of agricultural products and foodstuffs sold under GIs in Europe from 2005 to 2010 and the evolution of the market share of the main GI products. 


\section{METHODOLOGY}

This research uses a qualitative approach based on the case study method (Eisenhardt, 1989; Yin, 2003). Case study research is increasingly important in agrifood supply chain studies as a means of collecting data and building and testing theory (Fredriksson and Liljestrand, 2015; Shukla and Jharkharia, 2013; Sterns et al., 1998). Because this paper is attempting theory-building research, it begins "as close as possible to the ideal of no theory under consideration and no hypotheses to test" (Eisenhardt, 1989, p. 536). In the analysis and interpretation of the data collected, we used the grounded theory technique to develop an inductive model and to move from our observations to a theoretical interpretation (Glaser and Strauss, 1967), without introducing preconceptions into the analysis (Glaser, 1992; Nair et al., 2016).

The advantage of case analysis is that it reveals small details that may become highly relevant for explaining a situation. The disadvantage is that only with a large number of cases is it possible to draw statistical conclusions (Shah and Corley, 2006; Van Maanen, 1979). Case study is considered a valid approach and an appropriate tool when the problem is not fully understood (Eisenhardt, 1989) and when the aim is to discover new variables and relationships to elucidate complex processes (Glaser and Strauss, 1967; Shah and Corley, 2006; Yin, 2003) or when the aim is to apply existing theory to new contexts (Barratt et al., 2011). The purpose is thus to formulate hypotheses based on a qualitative analysis.

The analysis undertaken follows the recommendations of Miles and Huberman (1994) and Barratt et al. (2011, p. 338) for a rigorous, inductive, qualitative case study: a) justification of the choice of case-based research methodology, b) a clearly stated unit of analysis, c) formalization of each case, d) the use of multiple cases, e) performance of both within-case and cross-case analyses, f) within-case analyses that focus on the salient characteristics of the relationships among the members of the supply chain and g) cross-case 
analyses that identify similarities and differences across supply chains and that highlight emerging patterns.

\subsection{Sampling}

Case selection followed theoretical sampling (Eisenhardt, 1989, p. 533; Eisenhardt and Graebner, 2007; Eisenhardt et al., 2016; Siggelkow, 2007) because the purpose is to highlight the distinct organizational supply chain characteristics of successful GIs compared with those of successful private trademarks. Theoretical sampling has recently been used in case studies in the field of SCM (Barratt and Barratt, 2011; Jayaram et al., 2014; Mena et al., 2013; Scholten and Schilder, 2015). The unit of analysis is the supply chain network behind each brand (either GI or private). There are two reasons to select the meat sector. First, the meat industry is particularly sensitive to quality and health issues (as the meat carcinogenicity and Bovine Spongiform Encephalopathy (BSE) crisis have shown). Second, it has quantitative importance in the GI field (see TABLE 1). The sampling followed two requirements:

a) Cases had to lead to a broad overview of the most prevalent mechanisms of governance for meat supply chains in Europe. Therefore, different meat products (beef, pork, poultry) that are produced in four EU countries (France, Italy, Spain and the United Kingdom) and that involve organizations associated with GIs and private trademarks were selected. Private trademark cases work as a control group that allows the identification of distinctive aspects in the supply chain organization of GIs.

b) Cases had to involve well-known and successful brands. Therefore, brands with a relevant market share and long-term survival and that were well known on a national level were selected. Only successful brands were chosen because the aim was to identify how such brands overcame organizational problems. GIs that failed might not share the same organizational features as successful cases. 
Successful private trademarks were selected to enable a fair comparison.

The data were obtained from several complementary sources. First, various types of secondary information (government statistics, industry and market reports, participants' web sites, etc.) were collected to determine the structure of the industry and the relevant market and to assess the economic importance of the selected brands. Second, primary data were obtained in each case mainly through interviews (see Appendix) and from internal company reports. Interviewees were selected among key nodes (or agents) in each network and by considering the need for several stakeholders' perspectives to triangulate the information in each case (Easterby-Smith and Lowe, 1991). A set of interviews was conducted with the main suppliers, retailers, and quality controllers to check the owner's information and to identify their problems and complaints. The interviews followed a semi-structured questionnaire based on the identification of quality control, coordination and motivation devices, and brand performance [4]. The conflicts and problems suffered by the brand throughout its existence were also covered in all the interviews. On average, five interviews (5.4) were conducted to build each case, ranging from two to seven. We conducted just two in the BonÁrea case because it is an integrated company that embraces the whole supply chain. Each interview lasted approximately two hours, and answers were recorded in writing. A team of trained researchers conducted the interviews in France, Italy, Spain and the UK. All the information on each case was summarized in a structured report. In the final analysis, five cases consisting of three GIs and two private trademarks were obtained. TABLE 2 shows a brief description of the selected cases.

-Insert TABLE 2 Approximately Here 


\section{CROSS-CASE ANALYSIS}

The aim in this section is to show how the implementation of a GI affects supply chain organization and to explain those changes. It compares the supply chain organization in GI cases to that where there is only a private trademark. The comparison proceeds in two steps. First, supply chain organization is compared across cases but within the same category to extract their regularities, and then the organization is compared across categories (GI vs. private trademark) to highlight their differences and to induce a general explanation.

\subsection{Across cases and within category comparison}

\subsubsection{Some Regularities from the GI Cases}

First, all three cases began as legitimate producers' reactions to other producers who were misleading consumers by selling products without the value-adding attributes associated with the geographical name; in other words, these producers engaged in commercial gimmickry. As Andy McGowan, head of industry development at Quality Meat Scotland, told FoodManufacture.co.uk in October 2011, "I suspect there's a fair bit of this going on because Scotch Beef commands a premium of $50 \%$ over the cheapest imports, which makes it an attractive target for substitution” (http://www.foodmanufacture.co.uk/Ingredients/Meatindustry-calls-time-on-rogue-traders-fraud). In July 2011, the Ministry of Rural Affairs and Fisheries of the Principality of Asturias (Spain) also denounced the commercialization of "substitutes" for Ternera Asturiana that were sold under names such as "beef Asturias" and that constituted true "unfair competition and fraud" for consumers and farmers (http://www.infocarne.com/noticias/2011/7/4271_la_ternera_asturiana_crisis.asp). In addition, Paolo Facioni, a representative of the Italian farm lobby Coldiretti, stated in 2008 that "PDO and PGI products account for some $\$ 14$ billion in annual sales - but the figure would be much higher if consumers always bought the real thing. Late last year, authorities seized some 1,000 hams from warehouses and supermarkets throughout Italy. The haul may have just been the tip 
of the iceberg: Investigators say there's no way of telling just how many hams had already vanished into stomachs in the guise of the coveted Parma or San Daniele varieties in the massive PDO scam" (http://usatoday30.usatoday.com/news/world/2008-07-12487770843_x.htm). This type of misbehavior is particularly harmful when the place name is valued for commercial purposes (Anania and Nisticò, 2004; Menapace and Moschini, 2012; Raynaud et al., 2005; Yeung and Kerr, 2011), and it is the main reason (weak institutions) for which firms implement non-market strategies (Dorobantu et al., 2017).

Second, GI networks combine two types of participants and two levels of governance, with one type in each level (see FIGURE 2). On the one hand, there are firms that perform production, processing and distribution; these firms make up the traditional supply chain and use their own private trademarks to identify their products. They form what we refer to as the "private level" of governance because they are involved in dyadic transactions, and the parties to these transactions freely decide how to organize their relationships. By "traditional," we are referring to both physical and support supply chains, as explained by Carter et al. (2015). On the other hand, there are institutions that are involved in the overall regulation and control of these activities (e.g., governing and inspection bodies). They mark the products that pass their controls by adding a new commercial brand: the GI brand. These institutions constitute the "public level" of governance because they were designed by the GI regulators. The GI control and regulatory institutions are part of the support supply chain. These two types of participants and levels of governance entail a substantial separation of production resources ownership (private level) as well as ownership of and quality control over the GI brand (public level). 
Third, the governing body (consortium, council or association) is a key player within GIs. The (local or national) government, i.e., the real/ultimate owner of the brand, delegates many decision rights to it. The governing body is in charge of drafting and approving the technical rules. It sets forth a detailed list of specifications that must be fulfilled by participants in the supply chain (see TABLE 3). By itself, or through an inspection body, it controls membership by checking ex ante that any agents seeking to become members of the GI (producers, distributors, retailers, etc.) comply with the requirements. It ensures ex post that all the members abide by the regulations, thus guaranteeing that the product continues to adhere to the pre-established quality standards. It has the power to impose penalties in case of breaches of specifications, the harshest penalty being exclusion of a member from the GI (i.e., denial of the right to use the geographical name as a commercial trademark). Finally, participants may introduce additional controls or exigencies in their own transactions (provided that the GI specifications are observed) to differentiate themselves.

-Insert TABLE 3 Approximately Here

Fourth, transactions among companies engaged in production, processing and distribution (private level) are typically market-oriented. The parties negotiate basic contractual features such as price and quantity. The governance of supply chains is characterized by a rather complex network of relationships, most of which are based on longterm, informal contracts. As a GI farmer states, "I'm not committing myself to anyone, at least formally. I sell to those who pay the most, taking into account the quality. Certainly, I have a set of regular customers, and I frequently end up working with them because it is easier to reach an agreement and I know that they are reliable and that they don't shirk." It is true that forward or backward vertical integration processes occur in certain steps (i.e., the 
slaughtering stage and ham production in Parma), but it is not frequently observed in any GI case.

These regularities corroborate the idea that inter-firm collaborations are of paramount importance in the agrifood sector (Cox et al., 2007; Matopoulos et al., 2007). The adoption of a GI is simply a joint response of the supply chain participants to some producers' misbehavior. GI regulation therefore represents an institutional arrangement to curb opportunism and to preserve geographical brand name equity. It is interesting to note that, apart from supply chain resources such as information, technology, incentives, risks, people and trust (Cao et al., 2010; Fawcett et al., 2008; Matopoulos et al., 2007), an additional key element for promoting cooperation is the institutional environment (Dorobantu et al., 2017). To the best of our knowledge, GIs as a type of institutional arrangement have not been identified as a facilitator of supply chain cooperation.

\subsubsection{Some Regularities from the Private Trademark Cases}

First, the only relevant participants in the supply chain are firms engaged in production, processing and distribution. The owners only use their own private trademarks to identify their products. Therefore, only what it has been called the "private level" of governance appears in these cases (see FIGURE 3) [5].

-Insert FIGURE 3 Approximately Here

Second, tight vertical coordination occurs among the participants in the supply chain either through vertical integration, as in bonÁrea, or through long-term formal contracts, as in FQC. BonÁrea has established internal controls or tracking mechanisms (in-house controls), which means that it has the authority to decide whether the product does or does not comply with predefined specifications. When the transaction (or link) is not within the firm, 
inter-firm controls are added, such as in the case of FQC. These inter-firm controls are carried out along the supply chain on the initiative of Carrefour, although it has hired independent controllers. Each participant is then controlled by Carrefour, whose reputation is at risk in the final market. A Carrefour manager said, "We are looking for 'completely traceable' meat" in order to determine who to blame when a problem is detected. To achieve this, calves are marked with an eartag and included in a database to monitor all their vital processes and their movements. In both cases, the aim of the controls is to verify compliance with the established specifications and to guarantee a standardized production process (see TABLE 4). The managers of both private trademarks noted that "all quality control activities and costs are borne by the firm."

The result that private trademarks tend to use non-market mechanisms of governance fits well with previous papers in various literatures that describe a trend in many agrifood sectors (including the meat sector) toward tighter vertical coordination to guarantee quality (Anastasiadis and Poole, 2015; Díez-Vial, 2007; Fearne, 1998; Fearne and Hughes, 1999; Harrigan, 1985; Hobbs and Young, 2000; Jang and Olson, 2010; Ménard and Klein, 2004; Wagner and Alderdice, 2006). Furthermore, the Carrefour case resonates with insights from Mena et al. (2013). When a buyer wants to influence key characteristics of the final product whose quality depends on various steps in the chain, it has to create direct connections to these steps. Slaughterhouses and farmers have a strong impact on the final quality in the FQC case. Through a set of trilateral contracts with abattoirs and farmers' associations, Carrefour has created a direct, formal connection to both its suppliers and its suppliers' suppliers. This finding is also related to that of Cox et al. (2007), who emphasize the importance for firms to link their sourcing and branding strategies. 


\subsection{Across cases and between categories comparison: GI vs private trademark cases}

A significant organizational change is detected in GIs compared to non-GI cases that involves the emergence of an additional level of governance, the public level, which interacts with the private level of governance in reducing free riding on quality and enhancing geographical brand equity. The rise of this novel public level of governance of the supply chain triggers an increase in the specialization of participants in quality control activities and a change toward more market-oriented transactions at the private level (dyadic relationships). We argue that these changes avoid redundancies when both levels of governance overlap and show their complementarities, as will be discussed below.

\subsubsection{The Emergence of an Additional Level of Governance in GIs}

FIGURE 2 and FIGURE 3 show a simplification of the supply chain organization in both GIs and private trademark cases, respectively. If both figures are compared, the main organizational difference is the emergence of an additional (public) level of governance in the GI cases. Its organization rests with a collective decision-making body, the governing body, which manages and enforces the collective rules. Decision rights over the geographical brand are thus collectively defined and managed to protect and enhance its value. This public level carries out its own quality controls without regard to the in-house and inter-firm quality controls developed for firms participating at the private level (see TABLE 3) and can impose sanctions according to an approved code (including exclusion from the GI).

The rationale behind this public level of governance in GIs is to develop some sort of institutional arrangement to prevent free riding over quality. One interviewed manager of a governing body clearly illustrated this approach: "The main problem faced by producers prior to the emergence of the GI was that lots of products that did not meet the required conditions were sold on the market as genuine products. But because the brand did not have an 'owner,' no one could take any kind of effective measure against those who were cheating the 
customer with imitations of worse quality." Preventing quality debasement is a major concern in a GI due to $a$ ) the common-pool nature of the brand (Winfree and McCluskey, 2005) and $b$ ) because product acceptance is based on its uniqueness, which requires a differentiation strategy to emphasize quality (Dentoni et al., 2012; Fotopoulos and Krystallis, 2003; Mattia, 2004). The GIs' challenge is therefore to preserve territorial linkage and traditional production methods while assuring quality to consumers. The counterfeit activities undertaken by some producers before the institutionalization of the GI were particularly harmful because they directly undermined the legitimate producers' commercial strategy, which was based on using the place name as a sign of differentiation. The GI therefore frames the collaboration among these legitimate producers to protect the GI's brand equity and strengthen its market success.

At least four devices established at the public level of GIs are combined to mitigate the free riding problem. The first mechanism is to facilitate product identification vis-à-vis consumers. In fact, the governing bodies in GIs exert great effort to differentiate genuine products by adding their own logos and identifying devices to the GI Union symbol [6]. TABLE 3 shows how each item, apart from the Union symbol, has logos that should be used on the label or packaging of products whose names have been registered as a GI to protect "official" products from imitators. For example, Prosciutto di Parma applies a tattoo on the back of each leg of each pig, identifies each leg at the slaughterhouse by a firebrand, prints a seal on each mature ham and brands each pack of sliced ham. Scotch Beef producers are the only producers in the United Kingdom to use the figure " 1 " at the beginning of the country code in their product labeling. Ternera Asturiana identifies each calf by means of an ear tag that accompanies the animal until it is slaughtered. At the slaughterhouse, each carcass or piece is identified by marking it with a numbered label.

Second, the governing body formally establishes the general "rules of the game", including, in particular, the minimum quality attributes for all products sold under the GI 
brand. TABLE 3 details the specifications to be fulfilled for each GI brand considered. Third, the governing body decides on the membership (i.e., entitling certain firms to use the geographical name). TABLE 3 shows that all of the GI cases define this geographical origin and other ex ante membership conditions. Applicants must fulfill these criteria as well as any additional settled specifications for the production process. Commitment is formalized through a formal membership contract between individual members and the governing body.

Fourth, regular checks are undertaken by the governing body, either directly or through an inspection body, to ensure compliance with the requirements and to facilitate traceability in the event of problems (see TABLE 3, right hand column for quality controls at each step). One of the interviewed managers said, "I think that the controls are fairly strict. In addition, some inspections are unannounced. Inspectors appear at the farm without notice, they check all documents and contrast them with the animals, and they even take samples." The governing body is in charge of sanctioning any member who violates the quality specifications. For harsh or repeated breaches, members may put their membership at risk (and their use of the valuable geographical name). The threat of exclusion acts as a credible sanction and consequently will work as a bonding device only if excluded members suffer real economic losses, which in the GI context come from two different sources. On the one hand, GI-specific investments are a clear example because their value would be lost or reduced in the case of exclusion (Rokkan et al., 2003). On the other hand, the empirical literature argues that a GI brand adds a price premium (Areté, 2013; Chever et al., 2012; Fernández-Barcala and González-Díaz, 2006; Moschini et al., 2008; Van Ittersum et al., 2007), which will also be lost, at least partially, if members are banned from using the GI brand. The price premium provides members with a flow of income that exceeds the income that would be obtained without brand differentiation. One of the interviewed managers said, "I am interested in belonging to the brand because I can charge a higher price." This 
additional value compensates for both the (probable) higher cost of producing according to the GI rules and the specific investments in developing the brand.

In sum, the GI system solves the free riding problem by cooperating in the implementation of a public level of governance that takes the property rights over the geographical name out of the general public domain and allocates them to a governing body [7]. Once the GI is constituted, its governing body (public level) establishes in writing the general "rules of the game" and the minimum attributes (specifications) to be fulfilled by each authorized brand producer and each product sold under the GI brand. This body also verifies and enforces compliance with specifications, punishing producers who do not meet the standards. Consequently, and because of the theory-building objective of this study, it is possible to infer the following proposition from this finding.

Proposition 1: Overcoming the free riding problem that the use of a geographical name (i.e., a common-pool resource) yields in a supply chain requires the introduction of institutional arrangements (public governance level) to promote multilateral cooperation.

\subsubsection{Complementarity between Levels of Governance in GIs}

The above analysis shows that GI supply chains have an extra level of governance compared with supply chains for products bearing only a private trademark. In this manner, a duality is created that goes from decision-making and quality control along the entire supply chain to the existence of co-branding in the end product. The argument is that these two levels of governance complement one another, thus rendering the entire governance mechanism synergistic. Complementarity here means a beneficial interplay in the design elements of a system (Ennen and Richter, 2010; Lafontaine and Slade, 2013; Milgrom and Roberts, 1995). The key argument is that each level of governance (public and private) compensates for the relative weaknesses of the other in protecting and enhancing the GI brand equity. In particular, complementarity requires overcoming free riding and ensuring that supply chain 
participants have the right incentives to invest to improve the quality of the GI products while simultaneously avoiding redundancy in their joint functioning. These results are coherent with the ambidextrous governance observed by Blome et al. (2013) in manufacturing firms, and they extend the range of organizational complementarities (Ennen and Richter, 2010) to include public governance. The following organizational changes substantiate the synergetic influence between the two levels of governance.

Specialization in Quality Control. Quality control in GIs can be undertaken by both public and private levels of governance (see FIGURE 2). However, each level specializes in implementing such control on different types of matters. The public level performs quality control related to GI brand specifications and penalizes/excludes noncompliant members. For example, the governing body in Ternera Asturiana is responsible for microbiological analyses in which samples of eyes, thyroids, and kidneys are randomly collected to analyze and verify whether growth stimulants have been used (which are prohibited within the brand). Additionally, the seal applied to each fresh Parma ham with a code indicating the starting date of maturing at the ham factory and the firebrand applied to each mature ham by the inspection body personnel make it unnecessary for distributors and retailers to check that the minimum periods of maturity have been met. These controls ensure product traceability and that the GI product meets the specifications laid down in its regulations. Different authors agree that both the introduction of standards (specifications) and assurances about their compliance coordinate the supply chain vertically, thus reducing information asymmetries and breaches in quality (Banterle and Stranieri, 2008; Ciliberti et al., 2009; Pilbeam et al., 2012; Wever et al., 2010).

This specialization of the GI governing body in controlling compliance with respect to the specifications makes it unnecessary for those checks to be replicated at the private level. In fact, participants in the supply chain who believe that the GI specifications and controls are 
harsh enough do not perform additional/stricter quality controls. These quality controls are established only when GI participants at the private level believe that the GI product specifications do not sufficiently differentiate their end product (Dentoni et al., 2012). There are important private trademarks within GIs, and products frequently show both a private trademark and a geographical brand. In fact, this GI co-branding has been highly emphasized in the marketing literature (Dufeu et al., 2014; Fernández-Barcala and González-Díaz, 2006). Participants in a physical supply chain can introduce either additional controls that are not undertaken within the GI or more restrictive lists of specifications (Xata Roxa and Wedderlie Farm, private producers within Ternera Asturiana and Scotch Beef, respectively, are examples of this situation). These participants enforce further specifications in addition to those required by the governing body.

Private participants in the physical supply chain within a GI might be interested in exerting this extra effort to improve quality because they are residual claimants over the return of their investments. This residual claimancy provides individual, high-powered incentives to improve the quality of the participant's products, i.e., products labeled with the private participant's trademark. If the participant's quality improvement is successful, he/she earns the residual return. In fact, coordination provided by the public level of governance does not guarantee that participants in the supply chain are interested in inducing the continuous quality improvement required for the survival and success of the GI brand over the long term. Instead, it only ensures that the current specifications are met. Nonetheless, quality improvements may be critical to the long-term success of the companies (Powell, 1995) and to the GI. The required motivation is then achieved at the private level of governance.

Although such improvements initially only raise the quality of the pioneering member, they may eventually benefit others. First, because GI products are typically labeled with two brands, quality improvements by a particular producer may indirectly enhance the quality 
perception of the entire line of GI products (and vice versa; see Menapace and Moschini, 2012). Second, because initial improvements may be progressively adopted by the entire set of members, amendments of the initial "official" specifications are even possible. However, modifying the initial quality specification is not always easy as some members may resist implementation of any improvements (Dentoni et al., 2012).

Moreover, the virtuous effect of residual claimancy, i.e., high-powered incentives to innovate, may come at the expense of disrespect of the GI standards [8]. In fact, it is precisely firms' status as a residual claimant that brings about the need to use a mechanism (public monitoring) to curb the tendency of GI members to maximize their own profit at the expense of the overall chain. As stressed above, free riding is a real issue, and the public governance level is in charge of controlling it. Apart from direct supervision of the GI inspection body, the fear of exclusion from the GI is again a bonding device: GI exclusion means the loss of GI-specific investments and the price premium for using the GI brand.

None of the levels of governance alone is able to offer a similar combination of coordination and incentives for GI participants. Thus, the public level of governance mitigates free riding and enhances coordination by monitoring compliance with the GI quality specifications. However, without the high-powered incentives of the private level, the public level would not be able to motivate the parties to invest in quality improvements. Nevertheless, this strong motivation sometimes comes at the expense of deviating from the collective rules, which places the GI brand equity at risk. This value is only protected by the public level of governance. In short, the two levels work in tandem and complement - rather than substitute - for one another.

Reaching Vertical Coordination in GIs. Various organizational arrangements, from vertical integration to more market-oriented relationships (Williamson, 2008), can govern the links between the nodes of the physical supply chain (Mena et al., 2013). GI and non-GI supply 
chain participants choose how to effectively organize the links between nodes. However, a striking difference between the GI and non-GI cases arises that involves the degree of vertical integration in the physical supply chains (private level of governance). As stressed before, "market-oriented" modes of governing transactions prevail in supply chain dyads within GIs. In Prosciutto di Parma, vertical integration only prevails between the slaughtering stage and ham production. Transactions among the other links in the chain are mainly market-oriented. In the Scotch Beef case, most of the relationships are informal spot contracts; the exception is the relationships between some abattoir/meat processors and the largest retailers, which are primarily exclusive partnerships. Similarly, spot and informal transactions prevail between the nodes of the physical supply chain in Ternera Asturiana. "All agreements are established orally; there are no written contracts," asserted an interviewed cattle breeder. Rarely do distributors have their own cattle farm. By contrast, explicit long-term contracts and/or vertical integration are the most prevalent mechanisms of governance in the supply chains of the private trademarks analyzed herein. In FQC, formal, long-term contracts govern transactions in the supply chain, whereas in BonÁrea, vertical integration prevails.

The prevalence of market-oriented transactions in GI supply chains seems to contradict some of the propositions derived from TCE. In particular, when strong coordination among chain members is required, for instance to assure quality all along the chain, TCE would predict vertical integration or explicit contracts as the most efficient governance structure (Díez-Vial, 2007; Harrigan, 1985). Furthermore, this prediction is for any product for which tight supply chain coordination is required, irrespective of whether a GI exists or not. Chains with GIs and chains with only private trademarks have the same types of quality-related contractual hazards. Why do non-GI supply chains seem to be more vertically coordinated (and integrated) than GI supply chains?

We claim that there is no real difference and that it is mostly an "observational effect" 
linked to the considered unit of analysis. When the unit of analysis is the whole supply chain, i.e., both levels of governance, public and private, are considered together, tight vertical coordination in the GI supply chains is accomplished, just as in the non-GI cases, because vertical coordination to improve quality in the GI cases is achieved both through standardization and the monitoring activities of the governing body at the public governance level and through private governance forms at each dyad. Conversely, when the unit of analysis is only the transaction/link, loose vertical coordination is observed in the GI cases because we are not considering the coordination activities of the governing body at the public level. Dyads accommodate that institutional coordination effort by adapting their governance form to focus more on the parties' motivation than on coordination. This change at the private governance level toward more market-oriented transactions produces the observational effect of less vertical integration. However, it does not necessarily mean that a smaller level of vertical coordination is reached; rather, it is achieved in a different manner within GIs.

There are two explanations for this move. First, by providing public standardization, monitoring and certification at all stages of the chain, the GI system economizes on the need (and costs) to privately design monitoring mechanisms implemented through bilateral contracts in intermediate transactions (i.e., some kind of administrative controls in terms of Williamson (1991)). There is no need to replicate these controls at the private level. Additional and/or stricter controls are necessary only when the targeted level of differentiation is higher than that offered by the GI brand name. In this situation, arm's length transactions can be optimal because they take advantage of high-powered incentives without losing coordination (Williamson, 1991), which is provided by the public governance level. Second, the collective nature of GIs may also reduce the severity of the hold-up problem related to specific investments (Williamson, 1985). Investments to comply with GI quality specifications are more "GI-specific" than specific to a particular transaction with a given 
supply chain transactor. The collective nature of GIs increases the possibility of alternative exchange opportunities and thus reduces the prospect of bilateral dependency among a pair of transactors.

As a conclusion, and regarding the theory-building aim of the paper, the observed changes and the subsequent explanations can be formulated in terms of research propositions:

Proposition 2: The institutional arrangements (public level of governance) complement the dyadic mechanism of governance for enhancing quality.

Proposition 2.1 The overlapping of governance levels drives their specialization in different tasks (monitoring and motivation).

Proposition 2.2 The overlapping of governance levels changes the optimal dyadic governance form (fewer administrative controls are needed in the presence of a GI).

\section{CONCLUSIONS AND IMPLICATIONS}

The EU regulates the use of a place name that is valuable for commercial purposes by means of legal structures known as GIs. A GI grants the rights to use a geographical name as a commercial brand to a group of producers that fulfill a certain set of characteristics. This paper has sought to explain changes in the organization of supply chains when members of the chain that are localized in a specific area decide to adopt a GI as a collective commercial brand. A qualitative approach based on the case study method has been used because this research is exploratory and aims to build theory and because no previous studies have examined the influence of adopting GIs on SCM.

\subsection{Conceptual contribution}

Based on this qualitative approach, we compared GI and non-GI cases in the European meat sector. First, on their own, the private mechanisms that govern the relationships between participants in a supply chain cannot overcome the free riding problem associated with the use of common-pool resource (i.e., geographical name). Thus, when a geographical name is used as a brand in a supply chain, some type of public or collective level of governance is required 
(proposition 1). Its main goal is to promote cooperation among chain members, and it is operationalized through the creation of a governing body that is granted most of the property rights concerning the use of the place name as a commercial brand.

Second, it is claimed (proposition 2) that this new public level complements the traditional private level of governance, and both levels working together perform better than either does separately. Two sources of synergistic benefits have been identified: (i) task specialization between levels to simultaneously overcome free riding and quality improvement and (ii) organizational form adaptation to reduce administrative controls while providing incentives.

On the one hand, the institutional supply chain participant (i.e., the GI governing body) specializes in performing quality controls (standardization and controlling) so that it improves supply chain coordination. Meanwhile, the private governance level focuses on providing the parties with incentives to invest in quality improvement because such parties are residual claimants of the extra profits derived from these improvements, and consumers identify those producers who implement valuable quality innovations through their private trademarks (cobranding). Neither of these two levels of governance alone is able to offer a similar monitoring/incentive scheme in a situation in which a place name that is valuable for commercial purposes is present.

On the other hand, dyadic transactions along the GI supply chain (private level) move to more market-oriented mechanisms of governance than those in non-GI cases. This is because participants do not require long-term, formal contracts or administrative controls to coordinate vertically the supply chain. Relying on the coordination reached by the GI, it is optimal to keep the high-powered incentives provided by the arm's length transactions. We finally claim that this lower reliance on vertical integration in dyadic transactions does not necessarily mean lower vertical coordination because vertical coordination for improving quality is 
achieved in a different manner within GIs (both private and public levels of governance must be considered).

\subsection{Limitations and further research}

It is clear that more research is required to fully understand how GIs may affect the organization of a supply chain and in which situations the adoption of GIs is efficient. In particular, this research has not analyzed how the power balance and relationship stability would change. In addition, the propositions derived from our analysis would benefit from a more systematic longitudinal analysis using supply chains in various agrifood sectors. The empirical validity of our propositions could require econometric tests based on a large sample of situations. Finally, while GIs are a widespread phenomenon in European food industries, not all GIs perform equally well. Identification of the drivers of this heterogeneity in value creation requires additional analysis.

\subsection{Managerial implications}

The findings have several managerial implications. The observed organizational differences between GI and non-GI supply chains suggest a divergence in the coordination/motivation mechanisms that managers must implement in each case. A large body of literature already exists on the second type of supply chains, and our results confirm the importance of a brand owner's tight control over its suppliers. This finding supports the frequently observed tendency toward vertical integration or long-term contracts in the dyads and triads of non-GI brands. However, the management of supply chains with GIs is more complex, and managers must consider the following differential aspects for the management of their companies:

- First, if there is a geographical name that is valuable for commercial purposes, managers should join other supply chain participants to apply for a GI, which can provide a useful framework for participants' cooperation to protect the geographical 
brand name equity against potential infringements.

- Second, firms involved in a GI should delegate its management to the collective governing body that reduces free riding by enforcing its rules and managing membership. This governing body should specialize in standardization, monitoring and enforcing the geographical attributes that define the GI.

- Third, managers should adopt a strong co-branding strategy to build their own private trademarks within a GI, which allows them to reap the profits they can make from individual quality improvements and favors synergetic effects with the geographical brand.

- Fourth, while managers of companies involved in a GI delegate quality control of the GI to the governing body, they should also establish extra quality controls only if these controls guarantee the presence of certain attributes that are not included in (or that are of a higher level than) the specifications of the GI.

- Fifth, each GI participant should strive for its own balance between vertical coordination and incentives while understanding that the governing body of the GI promotes the coordination of the network but does not provide incentives to create value at the company level. Managers should design their own vertical integration policy (nodes and links) to provide such incentives. 


\section{REFERENCES}

Anania, G. and Nisticò, R. (2004), "Public regulation as a substitute for trust in quality food markets: what if the trust substitute cannot be fully trusted?", Journal of Institutional and Theoretical Economics JITE, Vol. 160 No. 4, pp. 681-701.

Anastasiadis, F. and Poole, N. (2015), "Emergent supply chains in the agrifood sector: insights from a whole chain approach", Supply Chain Management: An International Journal, Vol. 20 No. 4, pp. 353-368.

Areté (2013), "Study on assessing the added value of PDO/PGI products, executive summary", available at: http://ec.europa.eu/agriculture/external-studies/added-valuepdo-pgi_en.htm (accessed 24 April 2015).

Banterle, A. and Stranieri, S. (2008), “The consequences of voluntary traceability system for supply chain relationships. An application of transaction cost economics”, Food Policy, Vol. 33 No. 6, pp. 560-569.

Barratt, M. and Barratt, R. (2011), "Exploring internal and external supply chain linkages: evidence from the field", Journal of Operations Management, Vol. 29 No. 5, pp. 514528.

Barratt, M., Choi, T.Y. and Li, M. (2011), "Qualitative case studies in operations management: trends, research outcomes, and future research implications", Journal of Operations Management, Vol. 29 No. 4, pp. 329-342.

Becker, T. (2009), "European food quality policy: the importance of geographical indications, organic certification and food quality assurance schemes in European countries", Estey Centre Journal of International Law and TRADE Policy, Vol. 10 No. 1, pp. 111130. 
Blome, C., Schoenherr, T. and Kaesser, M. (2013), “Ambidextrous governance in supply chains: the impact on innovation and cost performance", Journal of Supply Chain Management, Vol. 49 No. 4, pp. 59-80.

Bouamra-Mechemache, Z. and Chaaban, J. (2010), "Determinants of adoption of protected designation of origin label: evidence from the French Brie cheese industry", Journal of Agricultural Economics, Vol. 61 No. 2, pp. 225-239.

Bradach, J.L. (1997), "Using the plural form in the management of restaurant chains", Administrative Science Quarterly, Vol. 42 No. 2, pp. 276-303.

Bureau, J. and Valceschini, E. (2003), "European food-labelling policy: successes and limitations", Journal of Food Distribution Research, Vol. 34 No. 3, pp. 70-76.

Cao, M., Vonderembse, M., Zhang, Q. and Ragu-Nathan, T.S. (2010), “Supply chain collaboration: conceptualisation and instrument development", International Journal of Production Research, Vol. 48 No. 22, pp. 6613-6635.

Carter, C.R., Rogers, D.S. and Choi, T.Y. (2015), "Toward the theory of the supply chain", Journal of Supply Chain Management, Vol. 51 No. 2, pp. 89-97.

Chever, T., Renault, C., Renault, S. and Romieu, V. (2012), "Value of production of agricultural products and foodstuffs, wines, aromatised wines and spirits protected by a geographical indication (GI)”, available at: http://ec.europa.eu/agriculture/externalstudies/2012/value-gi/final-report_en.pdf (accessed 23 September 2013).

Choi, T.Y. and Kim, Y. (2008), "Structural embeddedness and supplier management: a network perspective”, Journal of Supply Chain Management, Vol. 44 No. 4, pp. 5-13.

Ciliberti, F., de Groot, G., de Haan, J. and Pontrandolfo, P. (2009), “Codes to coordinate supply chains: SMEs' experiences with SA8000”, Supply Chain Management: An International Journal, Vol. 14 No. 2, pp. 117-127.

Coase, R.H. (1937), "The nature of the firm”, Economica, Vol. 4 No. 16, pp. 386-405. 
Costanigro, M., McCluskey, J.J. and Goemans, C. (2010), “The economics of nested names: name specificity, reputations, and price premia", American Journal of Agricultural Economics, Vol. 92 No. 5, pp. 1339-1350.

Cox, A., Chicksand, D. and Yang, T. (2007), “The proactive alignment of sourcing with marketing and branding strategies: a food service case", Supply Chain Management: An International Journal, Vol. 12 No. 5, pp. 321-333.

Dentoni, D., Menozzi, D. and Capelli, M.G. (2012), “Group heterogeneity and cooperation on the geographical indication regulation: the case of the 'prosciutto di Parma' Consortium", Food Policy, Vol. 37 No. 3, pp. 207-216.

Díez-Vial, I. (2007), “Explaining vertical integration strategies: market power, transactional attributes and capabilities", Journal of Management Studies, Vol. 44 No. 6, pp. 10171040.

Dorobantu, S., Kaul, A. and Zelner, B. (2017), "Nonmarket strategy research through the lens of new institutional economics: an integrative review and future directions", Strategic Management Journal, Vol. 38 No. 1, pp. 114-140.

Dufeu, I., Ferrandi, J.M., Gabriel, P. and Le Gall-Ely, M. (2014), “Socio-environmental multi-labelling and consumer willingness to pay", Recherche et Applications en Marketing, Vol. 29 No. 3, pp. 35-56.

Easterby-Smith, M.R.T. and Lowe, A. (1991), Management Research: An Introduction, Solid Action on Globalization and Environment, London, UK.

Eisenhardt, K.M. (1989), "Building theories from case study research”, Academy of Management Review, Vol. 14 No. 4, pp. 532-550.

Eisenhardt, K.M. and Graebner, M.E. (2007), “Theory building from cases: opportunities and challenges", Academy of Management Journal, Vol. 50, No. 1, pp. 25-32. 
Eisenhardt, K.M., Graebner, M.E. and Sonenshein, S. (2016), “Grand challenges and inductive methods: rigor without rigor mortis", Academy of Management Journal, Vol. 59, No. 4, pp. 1113-1123.

Ennen, E. and Richter, A. (2010), “The whole is more than the sum of its parts—or is it? A review of the empirical literature on complementarities in organizations", Journal of Management, Vol. 36 No. 1, pp. 207-233.

Fawcett, S.E., Magnan, G.M. and McCarter, M.W. (2008), "Benefits, barriers, and bridges to effective supply chain management”, Supply Chain Management: An International Journal, Vol. 13 No. 1, pp. 35-48.

Fearne, A. (1998), "The evolution of partnerships in the meat supply chain: insights from the British beef industry", Supply Chain Management: An International Journal, Vol. 3 No. 4, pp. 214-231.

Fearne, A. and Hughes, D. (1999), "Success factors in the fresh produce supply chain: insights from the UK", Supply Chain Management: An International Journal, Vol. 4 No. 3, pp. 120-131.

Fernández-Barcala, M. and González-Díaz, M. (2006), "Brand equity in the European fruit and vegetable sector: a transaction cost approach", International Journal of Research in Marketing, Vol. 23 No. 1, pp. 31-44.

Fotopoulos, C. and Krystallis, A. (2003), "Quality labels as a marketing advantage”, European Journal of Marketing, Vol. 37 No. 10, pp. 1350-1374.

Fredriksson, A. and Liljestrand, K. (2015), "Capturing food logistics: a literature review and research agenda", International Journal of Logistics Research and Applications, Vol. 18, No. 1, pp.16-34.

Glaser, B.G. (1992), Emergence vs Forcing: Basics of Grounded Theory Analysis, The Sociology Press, Mill Valley, CA. 
Glaser, B.G. and Strauss, A.L. (1967), The Discovery of Grounded Theory, Strategies for Qualitative Research, Aldine de Gruyter, New York, NY.

Gragnani, M. (2013), “The EU regulation 1151/2012 on quality schemes for agricultural products and foodstuffs", European Food and Feed Law Review, Vol. 6, pp. 376-385.

Harrigan, K.R. (1985), "Vertical integration and corporate strategy”, Academy of Management Journal, Vol. 28 No. 2, pp. 397-425.

Heide, J.B. (1994), “Interorganizational governance in marketing channels”, Journal of Marketing, Vol. 58 No. 1, pp. 71-85.

Hobbs, J.E. (1996), “A transaction cost approach to supply chain management”, Supply Chain Management: An International Journal, Vol. 1 No. 2, pp. 15-27.

Hobbs, J.E. and Young, L.M. (2000), “Closer vertical co-ordination in agri-food supply chains: a conceptual framework and some preliminary evidence", Supply Chain Management: An International Journal, Vol. 5 No. 3, pp. 131-143.

Jang, J. and Olson, F. (2010), "The role of product differentiation for contract choice in the agro-food sector”, European Review of Agricultural Economics, Vol. 37 No. 2, pp. 251-273.

Jayaram, J., Dixit, M. and Motwani, J. (2014), "Supply chain management capability of small and medium sized family businesses in India: a multiple case study approach”, International Journal of Production Economics, Vol. 147, pp. 472-485.

Ketchen, Jr., D.J. and Hult, G.T.M. (2011), "Building theory about supply chain management: some tools from the organizational sciences", Journal of Supply Chain Management, Vol. 47 No. 2, pp. 12-18.

Lafontaine, F. and Slade, M. (2013), “Inter-firm contracts: evidence”, in Gibbons, R., Roberts, J. (Eds.), The Handbook of Organizational, Economics, Princeton University Press, Princeton, NJ, pp. 958-1013. 
Landon, S. and Smith, C.E. (1998), "Quality expectations, reputation, and price”, Southern Economic Journal, Vol. 64 No. 3, pp. 628-647.

Loureiro, M.L. and McCluskey, J.J. (2000), “Assessing consumer response to protected geographical identification labeling”, Agribusiness, Vol. 16 No. 3, pp. 309-320.

Masten, S.E. (1996), "Empirical Research in transaction-cost economics: progress, challenges, directions", in Groenewegen, J. (Ed.), Transaction Cost Economics and Beyond, Kluwer Publishers, Academic \& Publishing House Publishers, Boston, MA, pp. 41-64.

Mathewson, G.F. and Winter, R.A. (1985), "The economics of franchise contracts", The Journal of Law and Economics, Vol. 28, No. 3, pp. 503-526.

Matopoulos, A., Vlachopoulou, M., Manthou, V. and Manos, B. (2007), “A conceptual framework for supply chain collaboration: empirical evidence from the agri-food industry", Supply Chain Management: An International Journal, Vol. 12 No. 3, pp. 177-186.

Mattia, G. (2004), "Balsamic vinegar of Modena. From product to market value: competitive strategy of a typical Italian product”, British Food Journal, Vol. 106 No. 10-11, pp. 722-745.

Mena, C., Humphries, A. and Choi, T.Y. (2013), "Toward a theory of multi-tier supply chain management”, Journal of Supply Chain Management, Vol. 49 No. 2, pp. 58-77.

Menapace, L. and Moschini, G. (2012), "Quality certification by geographical indications, trademarks and Firm reputation", European Review of Agricultural Economics, Vol. 39 No. 4, pp. 539-566.

Ménard, C. and Klein, P.G. (2004), "Organizational issues in the agrifood sector: toward a comparative approach", American Journal of Agricultural Economics, Vol. 86 No. 3, pp. $750-755$. 
Ménard, C. and Valceschini, E. (2005), "New institutions for governing the agri-food industry", European Review of Agricultural Economics, Vol. 32 No. 3, pp. 421-440.

Miles, M.B. and Huberman, M. (1994), Qualitative Data Analysis: An Expanded Sourcebook, 2nd ed, Sage Publications, Newbury Park, CA.

Milgrom, P. and Roberts, J. (1995), “Complementarities and fit strategy, structure, and organizational change in manufacturing”, Journal of Accounting and Economics, Vol. 19 No. 2-3, pp. 179-208.

Moschini, G., Menapace, L. and Pick, D. (2008), "Geographical indications and the competitive provision of quality in agricultural markets", American Journal of Agricultural Economics, Vol. 90 No. 3, pp. 794-812.

Nair, A., Yan, T., Ro, Y.K., Oke, A., Chiles, T.H. and Lee, S.-Y. (2016), “How environmental innovations emerge and proliferate in supply networks: a complex adaptive systems perspective", Journal of Supply Chain Management, Vol. 52 No. 2, pp. 66-86.

Ostrom, E. (2010), "Beyond markets and States: polycentric governance of complex economic systems", American Economic Review, Vol. 100 No. 3, pp. 641-672.

Pilbeam, C., Alvarez, G. and Wilson, H. (2012), “The governance of supply networks: a systematic literature review”, Supply Chain Management: An International Journal, Vol. 17 No. 4, pp. 358-376.

Ponte, S. and Gibbon, P. (2005), "Quality standards, conventions and the governance of global value chains", Economy and Society, Vol. 34 No. 1, pp. 1-31.

Poppo, L. and Zenger, T. (2002), "Do formal contracts and relational governance function as substitutes or complements?”, Strategic Management Journal, Vol. 23 No. 8, pp. 707725. 
Powell, T.C. (1995), “Total Quality Management as competitive advantage: a review and empirical study”, Strategic Management Journal, Vol. 16, No. 1, pp. 15-37.

Puranam, P., Gulati, R. and Bhattacharya, S. (2013), "How much to make and how much to buy? An analysis of optimal plural sourcing strategies", Strategic Management Journal, Vol. 34 No. 10, pp. 1145-1161.

Quality Meat Scotland (2015a), "The Scottish red meat industry profile 2015 edition”, available at: http://www.qmscotland.co.uk/scottish-red-meat-industry-profile-2015 (accessed 30 July 2015).

Quality Meat Scotland (2015b), “Annual Reviews, 2013/14”, available at: http://www.qmscotland.co.uk/qms-annual-review-20132014 (accessed 30 July 2015).

Raynaud, E., Sauvee, L. and Valceschini, E. (2005), “Alignment between quality enforcement devices and governance structures in the agro-food vertical chains", Journal of Management \& Governance, Vol. 9 No. 1, pp. 47-77.

Rokkan, A.I., Heide, J.B. and Wathne, K.H. (2003), "Specific investments in marketing relationships: expropriation and bonding effects", Journal of Marketing Research, Vol. 40 No. 2, pp. 210-224.

Schepker, D.J., Oh, W.-Y., Martynov, A. and Poppo, L. (2014), “The many futures of contracts: moving beyond structure and safeguarding to coordination and adaptation”, Journal of Management, Vol. 40 No. 1, pp. 193-225.

Scholten, K. and Schilder, S. (2015), "The role of collaboration in supply chain resilience", Supply Chain Management: An International Journal, Vol. 20 No. 4, pp. 471-484.

Shah, S.K. and Corley, K.G. (2006), "Building better theory by bridging the quantitativequalitative divide”, Journal of Management Studies, Vol. 43 No. 8, pp. 1821-1835. 
Shukla, M. and Jharkharia, S. (2013), “Agri-fresh produce supply chain management: a stateof-the-art literature review", International Journal of Operations and Production Management, Vol. 33 No. 2, pp. 114-158.

Siggelkow, N. (2007), "Persuasion with case studies", Academy of Management Journal, Vol. 50 No. 1 , pp. 20-24.

Sterns, J., Schweikhard, D.B. and Peterson, H.A. (1998), "Using case studies as an approach for conducting agribusiness research", International Food and Agribusiness Management Review, Vol. 1 No. 3, pp. 311-327.

Tachizawa, E.M. and Wong, C.Y. (2015), “The performance of green supply chain management governance mechanisms: a supply network and complexity perspective", Journal of Supply Chain Management, Vol. 51 No. 3, pp. 18-32.

Van Ittersum, K., Meulenberg, M.T.G., Van Trijp, H.C.M. and Candel, M.J.J.M. (2007), “Consumers' appreciation of regional certification labels: a Pan-European study", Journal of Agricultural Economics, Vol. 58 No. 1, pp. 1-23.

Van Maanen, J.V. (1979), "Reclaiming qualitative methods for organizational research: a preface", Administrative Science Quarterly, Vol. 24 No. 4, pp. 520-526.

Wagner, B.A. and Alderdice, A.D.G. (2006), "Managing the distribution channel: the case of Scot trout and Salmon”, Supply Chain Management: An International Journal, Vol. 11 No. 2, pp. 104-107.

Wever, M., Wognum, N., Trienekens, J. and Omta, O. (2010), “Alignment between chain quality management and chain governance in EU pork supply chains: a transactioncost-economics perspective”, Meat Science, Vol. 84 No. 2, pp. 228-237.

Wever, M., Wognum, P.M., Trienekens, J.H. and Omta, S.W.F. (2012), “Supply chain-wide consequences of transaction risks and their contractual solutions: towards an extended 
transaction cost economics framework", Journal of Supply Chain Management, Vol.

48 No. 1, pp. 73-91.

Williamson, O.E. (1985), The Economic Institutions of Capitalism, Macmillan, London, UK.

Williamson, O.E. (1991), "Comparative Economic Organization: the analysis of discrete

structural alternatives”, Administrative Science Quarterly, Vol. 36 No. 2, pp. 269-296.

Williamson, O.E. (2008), “Outsourcing: transaction cost economics and supply chain

management”, Journal of Supply Chain Management, Vol. 44 No. 2, pp. 5-16.

Winfree, J.A. and McCluskey, J.J. (2005), "Collective reputation and quality”, American

Journal of Agricultural Economics, Vol. 87 No. 1, pp. 206-213.

Yeung, M.T. and Kerr, W.A. (2011), “Are geographical indications a wise strategy for

developing country farmers? Greenfields, clawbacks and monopoly rents", The

Journal of World Intellectual Property, Vol. 14 No. 5, pp. 353-367.

Yin, R.K. (2003), Case Study Research: Design and Methods, 3rd ed, Solid Action on

Globalization and Environment, Beverly Hills, CA.

\footnotetext{
${ }^{1}$ The "private" level refers to how transactions among the various steps in the supply chain are organized to govern their upstream and downstream relations. We use the term "private" because it refers to dyadic relationships without government involvement. However, GIs in the EU introduce a "public" level of governance because the EU approves their creation and regulates their functions.

${ }^{2}$ Complementarity in business practices, such as the coexistence of formal and relational contracts and the use of plural forms in network businesses, has been previously studied. See, for example, Poppo and Zenger (2002), Bradach (1997), and Puranam et al. (2013). See Ennen and Richter (2010), Lafontaine and Slade (2013, p. 1001-4) and Schepker et al. (2014) for a review of complementarities in organizations.

3 http://www.europarl.europa.eu/sides/getAllAnswers.do?reference=E-2015-015801\&language=EN (accessed on May 6, 2016).

${ }^{4}$ The questionnaire is available upon request from the corresponding author.

${ }^{5}$ This classification involves setting aside other institutions that protect property rights and trademarks as well as safety and hygienic norms. Such institutions affect any link within the food supply chain because they are compulsory regardless of whether the nodes belong to a GI. Consequently, these institutions are not emphasized here because the analysis is looking for differential features between GI and non-GI cases, which these are not.

${ }^{6}$ The Union symbols that are referred to in Articles 12(2) and 23(2) of Regulation (EU) No 1151/2012 and established by Article 2 of Delegated Regulation (EU) No 664/2014 shall be reproduced as laid down in Annex X of the Commission Implementing Regulation (EU) No 668/2014 of 13 June 2014.

${ }^{7}$ In terms of the common goods literature, this process turns them into "toll" goods (Ostrom, 2010).

${ }^{8}$ It is worth noting that this problem is similar to the extensively analyzed franchisee's inclination to shirk in quality (Mathewson and Winter, 1985).
} 


\section{FIGURE 1}

Evolution of the Number of Registered GIs for Agricultural Farm Products and Foodstuffs in the EU

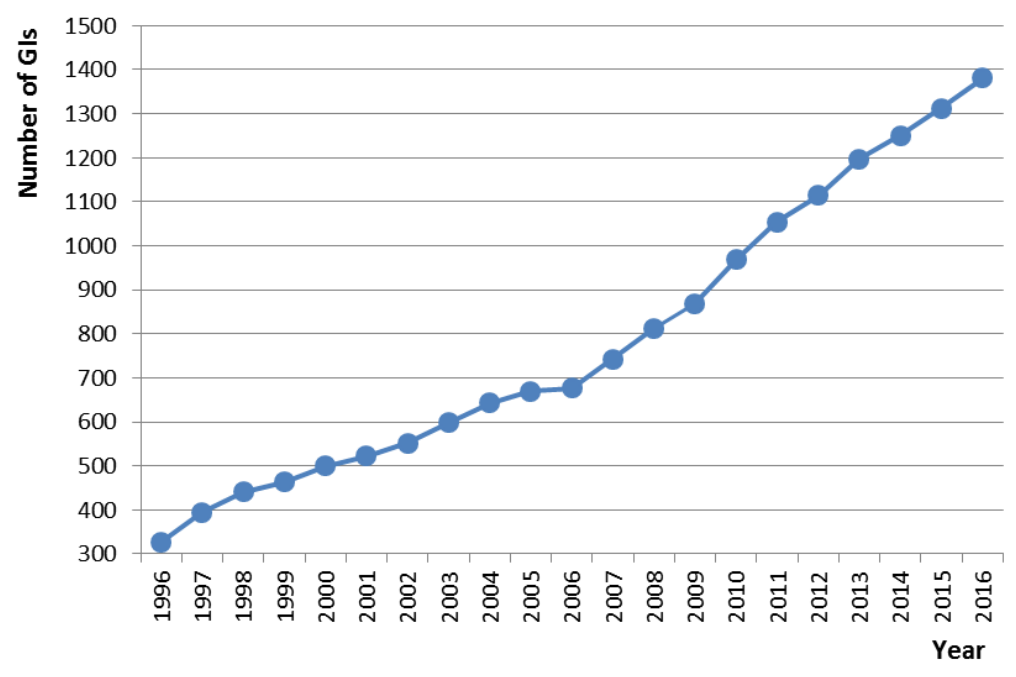

Source: DOOR database (http://ec.europa.eu/agriculture/quality/door/list.html, accessed on April 19, 2017). 
FIGURE 2

Supply Chain Organization in GIs

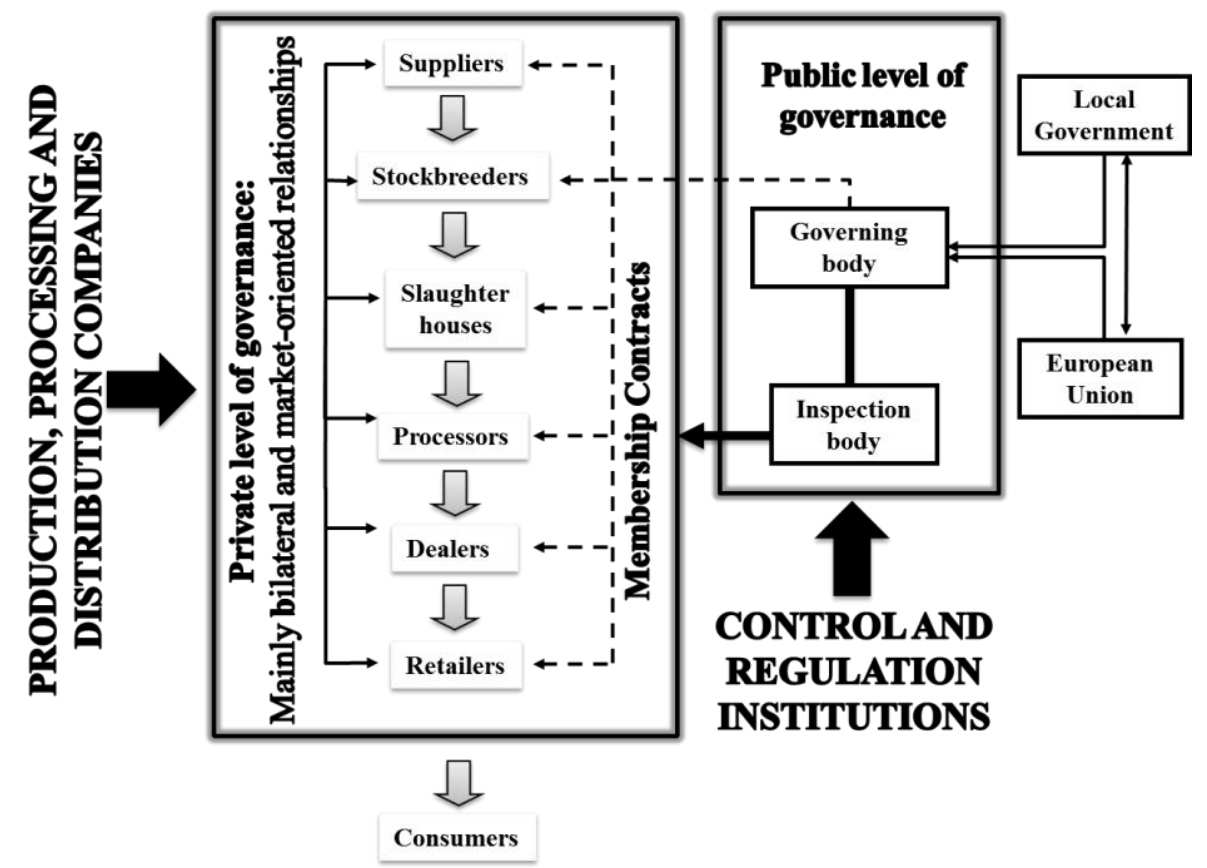




\section{FIGURE 3}

\section{Supply Chain Organization for Private Trademarks}
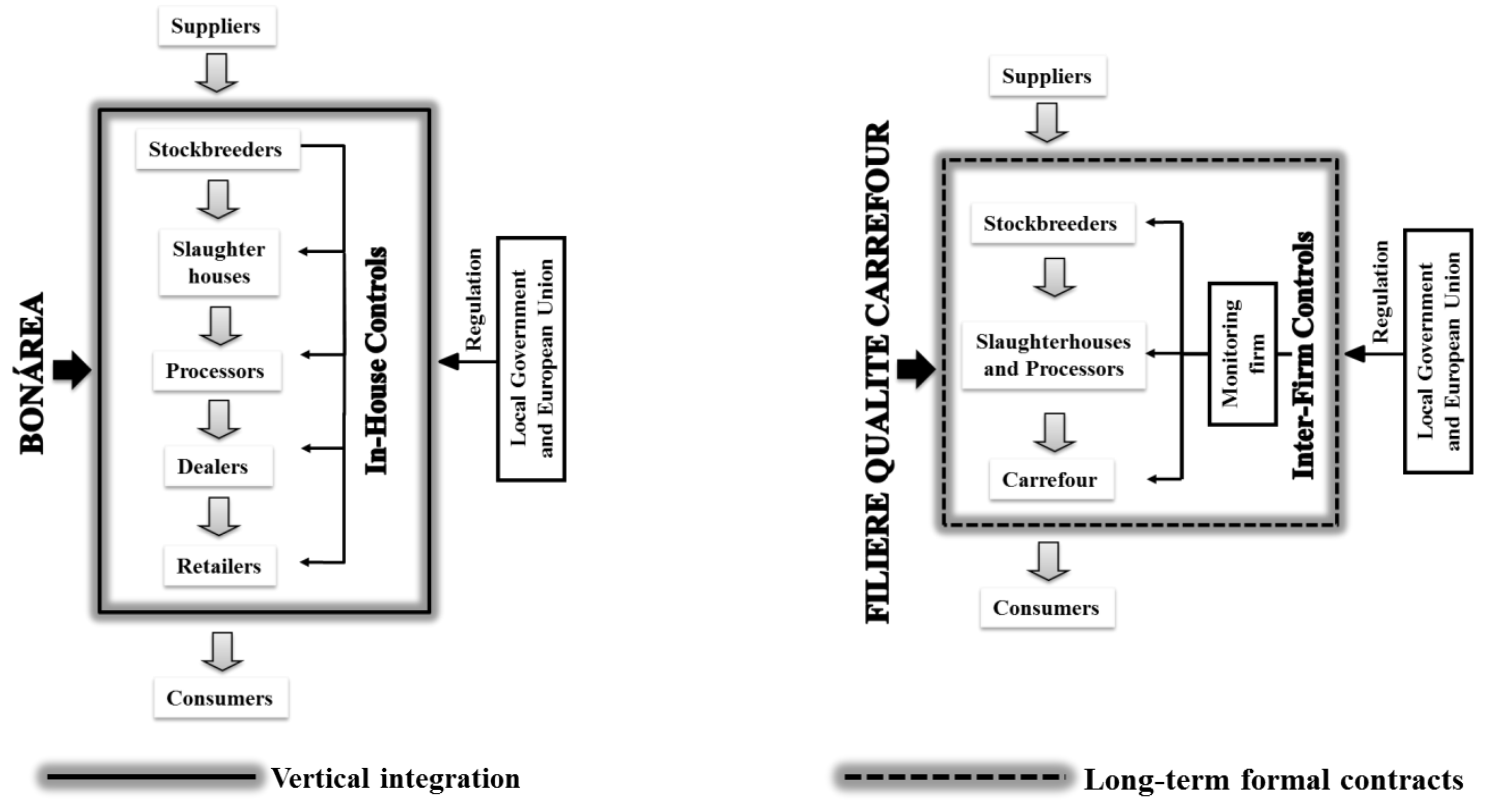
TABLE 1

Sales Value (€M) and Market Share (\%) of Agricultural Products and

Foodstuffs under GIs in the EU 27

\begin{tabular}{|l|c|c|c|c|c|c|}
\hline \multirow{2}{*}{ Product } & \multicolumn{4}{c|}{ Year } \\
\cline { 2 - 7 } & $\mathbf{2 0 0 5}$ & $\mathbf{2 0 0 6}$ & $\mathbf{2 0 0 7}$ & $\mathbf{2 0 0 8}$ & $\mathbf{2 0 0 9}$ & $\mathbf{2 0 1 0}$ \\
\hline \multirow{2}{*}{ Cheese } & 5,276 & 5,289 & 5,489 & 5,651 & 5,778 & 6,307 \\
& $(10.1 \%)$ & $(10.2 \%)$ & $(10 \%)$ & $(10 \%)$ & $(9.7 \%)$ & $(9.6 \%)$ \\
\hline \multirow{2}{*}{ Meat products } & 2,395 & 2,451 & 2,579 & 2,759 & 3,095 & 3,157 \\
& $(5.4 \%)$ & $(5.1 \%)$ & $(5 \%)$ & $(6.5 \%)$ & $(6.4 \%)$ & $(6.2 \%)$ \\
\hline \multirow{2}{*}{ Beer } & 2,301 & 2,407 & 2,361 & 2,390 & 2,390 & 2,364 \\
& $(5.5 \%)$ & $(5.5 \%)$ & $(5.5 \%)$ & $(6.2 \%)$ & $(6.7 \%)$ & $(6.8 \%)$ \\
\hline \multirow{2}{*}{ Fresh meat } & 1037 & 1011 & 1095 & 1116 & 1155 & 1244 \\
$(1.3 \%)$ & $(1.3 \%)$ \\
\hline Fruit, vegetables and cereals & $(1.3 \%)$ & $(1.3 \%)$ & $(1.3 \%)$ & $(1.3 \%)$ & $(1.3 \%$ & 978 \\
\hline Fresh fish, mollusks, and crustaceans & - & - & - & - & - & 443 \\
\hline Other products from Annex & 107 & 102 & 124 & 134 & 134 & 369 \\
\hline Oils and fats & 359 & 377 & 335 & 348 & 343 & 346 \\
\hline Bread, pastry, cakes... & 291 & 268 & 280 & 284 & 272 & 279 \\
\hline Natural mineral and spring waters & 145 & 146 & 144 & 145 & 143 & 143 \\
\hline Other products of animal origin & 48 & 45 & 47 & 49 & 68 & 71 \\
\hline Others & 25 & 68 & 71 & 73 & 55 & 87 \\
\hline \multicolumn{1}{|c|}{ TOTAL } & $\mathbf{1 3 , 2 8 4}$ & $\mathbf{1 3 , 4 5 7}$ & $\mathbf{1 3 , 8 9 1}$ & $\mathbf{1 4 , 2 3 8}$ & $\mathbf{1 4 , 5 2 5}$ & $\mathbf{1 5 , 7 9 0}$ \\
\hline
\end{tabular}

Source: Chever et al., 2012. 


\section{TABLE 2}

\section{Cases"}

\begin{tabular}{|c|c|c|c|c|c|c|c|}
\hline Brand & Product & Owner/Governing body & Country & $\begin{array}{l}\text { Mechanism of } \\
\text { governance }\end{array}$ & Production (2014) & Turnover (2014) & Interviews \\
\hline $\begin{array}{l}\text { Prosciutto di } \\
\quad \text { Parma }\end{array}$ & Pork & Consorzio del Prosciutto di Parma (consortium) & Italy & GI (PDO) & 8.8 million hams ${ }^{1}$ & $€ 1,500$ million $^{1}$ & $\begin{array}{l}6 \text { interviews with managers } \\
\text { (visiting } \\
\text { headquarters/facilities): } \\
\text { - } 1 \text { owner (governing body) } \\
\text { - } 1 \text { pig producer } \\
\text { - } 1 \text { abattoir } \\
\text { - } 2 \text { ham producers } \\
\quad 1 \text { quality monitor } \\
\end{array}$ \\
\hline Scotch Beef & Beef & Quality Meat Scotland (association) & United Kingdom & GI (PGI) & $\begin{array}{l}468,000 \text { beef cattle } \\
\text { slaughtered }^{2}\end{array}$ & $£ 675$ million $^{2}$ & $\begin{array}{l}6 \text { interviews with managers } \\
\text { (visiting } \\
\text { headquarters/facilities): } \\
\text { - } 1 \text { owner (governing body) } \\
\text { - } 2 \text { cattle breeders } \\
\text { - } 1 \text { auction } \\
\text { - } 1 \text { abattoir } \\
\text { - } 1 \text { retailer } \\
\end{array}$ \\
\hline Ternera Asturiana & Beef & Consejo Regulador de Ternera Asturiana (council) & Spain & GI (PGI) & $\begin{array}{c}21,137 \text { calves } \\
\text { slaughtered; } 5.47 \\
\text { million kilograms of } \\
\text { meat }^{3}\end{array}$ & $\begin{array}{c}€ 28.8 \text { million }^{4} \text { (in } \\
\text { 2015; data for } 2014 \\
\text { not available) }\end{array}$ & $\begin{array}{l}7 \text { interviews with managers } \\
\text { (visiting } \\
\text { headquarters/facilities): } \\
\text { - } 1 \text { owner (governing body) } \\
\text { - } 2 \text { producers } \\
\text { - } 1 \text { dealer } \\
\text { - } 1 \text { retailer } \\
\text { - } 1 \text { supplier } \\
\text { - } 1 \text { quality monitor } \\
\end{array}$ \\
\hline BonÀrea & $\begin{array}{l}\text { Varied meat } \\
\text { products }\end{array}$ & $\begin{array}{l}\text { Corporación Alimentaria de Guissona (private } \\
\text { firm) }\end{array}$ & Spain & Private trademark & \begin{tabular}{|c|}
34 million chickens, \\
1.6 million turkeys, \\
3.2 million quails, \\
676,000 pigs and \\
47,000 fattening \\
calves (includes only \\
direct sales through \\
"BonÀrea" own \\
shops)
\end{tabular} & $\begin{array}{c}€ 831 \text { million (food } \\
\text { products); } 74.13 \% \text { of } \\
\text { sales through the } \\
\text { "BonÂrea" own } \\
\text { shops }^{5}\end{array}$ & $\begin{array}{l}2 \text { interviews } \\
\text { - Visit to company } \\
\text { headquarters: Interview } \\
\text { with the Chairman of the } \\
\text { Agricultural Cooperative } \\
\text { of Guissona } \\
\text { - Visit to manufacturing } \\
\text { facilities: Interview with } \\
\text { facility manager } \\
\end{array}$ \\
\hline
\end{tabular}




\begin{tabular}{|c|c|c|c|c|c|c|c|}
\hline Brand & Product & Owner/Governing body & Country & $\begin{array}{l}\text { Mechanism of } \\
\text { governance }\end{array}$ & Production (2014) & Turnover (2014) & Interviews \\
\hline $\begin{array}{c}\text { Filiere Qualite } \\
\text { Carrefour }(F Q C)\end{array}$ & Beef & Carrefour (private firm) & France & Private trademark & $\begin{array}{l}12.5 \text { million } \\
\text { checkouts every day } \\
\text { in its stores }\end{array}$ & $\begin{array}{c}€ 100.5 \text { billion } \\
\text { (Carrefour sales } \\
\text { worldwide) }^{6}\end{array}$ & $\begin{array}{l}6 \text { interviews } \\
\text { - } 2 \text { managers in charge of } \\
\text { setting and negotiating the } \\
\text { system at the Carrefour } \\
\text { division responsible for } \\
\text { the FQC } \\
\text { - } 2 \text { managers of farmers' } \\
\text { association } \\
\text { - } 2 \text { managers of abattoirs }\end{array}$ \\
\hline
\end{tabular}

A detailed within-case analysis is available upon request from the corresponding author.

www.prosciuttodiparma.com, accessed on July 29, 2015.

Quality Meat Scotland (2015a, 2015b).

www.terneraasturiana.org/igp/estadisticas, accessed on July 30, 2015.

${ }^{4}$ www.terneraasturiana.org/5-442-ganaderias-forman-parte-ya-de-ternera-asturiana, accessed on September 28, 2016

${ }^{5}$ www.cag.es/grup/catala/16 04 15.asp, accessed on July 31, 2015.

6 www.carrefour.com, accessed on July 30, 2015. 


\section{TABLE 3}

\section{Specifications, Membership Restrictions and Control Devices in GIs}

\begin{tabular}{|c|c|c|}
\hline Brand & Specifications and membership restrictions & Control devices \\
\hline $\begin{array}{r}\text { Prosciutto } \\
\text { di Parma }\end{array}$ & $\begin{array}{l}\text { - Geographical origin } \\
\text { - Breed } \\
\text { - } \text { Breeding phase requirements (milking, weaning, fattening...) } \\
\text { - Minimum live weight of pigs before slaughter } \\
\text { - Maximum time for slaughter } \\
\text { - Quality scheme for pig carcass evaluation } \\
\text { - Limited ingredients for seasoning and salting } \\
\text { - Minimum period for ham maturation } \\
\text { - Traceability } \\
\text { - Official registers of members: stock farms, slaughterhouses, } \\
\text { ham producers, managed by IPQ; membership may be } \\
\text { withdrawn for non-compliance }\end{array}$ & $\begin{array}{l}\text { - Identification of young pigs at farms by a tattoo on } \\
\text { each back leg within } 30 \text { days of birth } \\
\text { - Checking written documentation of the breeder at the } \\
\text { slaughterhouse, certifying origin and tattoo and } \\
\text { evaluation of carcasses } \\
\text { - Identification at slaughterhouse by means of a fire } \\
\text { brand on each leg, approval and completion of } \\
\text { written documentation } \\
\text { - Checking the fire brand at the ham factory and the } \\
\text { written documentation for each piece } \\
\text { - New seal is applied to each fresh ham with a code } \\
\text { indicating the starting date at the ham factory } \\
\text { - Control of each mature ham and a new, easy-to-see } \\
\text { fire brand is applied to each ham or is printed on each } \\
\text { pack of sliced ham }\end{array}$ \\
\hline $\begin{array}{c}\text { Scotch } \\
\text { Beef }\end{array}$ & $\begin{array}{l}\text { - Geographical origin } \\
\text { - } \text { Feed composition and storage } \\
\text { - Stockmanship and welfare: housing and handling facilities } \\
\text { - } \text { Medicines and veterinary treatments: existence of a stock } \\
\text { - Livestock movement record book and medicine book must be } \\
\text { - } \text { up to date } \\
\text { - } \text { Auction mart standards } \\
\text { - Processor standards } \\
\text { - Traceability } \\
\text { - Commercialization standards } \\
\text { - Official registers of members: stock farms, auction markets, } \\
\text { slaughterhouses, meat plants and butchers managed by SFQC; } \\
\text { membership may be withdrawn for non-compliance }\end{array}$ & $\begin{array}{l}\text { - Control of origin of stock, housing and handling } \\
\text { facilities, feed composition and storage, medicine } \\
\text { and veterinary treatments, movement record and } \\
\text { medicine book, stockmanship and welfare, and staff } \\
\text { assessment at the farm level once per year } \\
\text { - Auction markets are controlled on market day } \\
\text { - In abattoirs and meat plants, the production process, } \\
\text { production environment, production and distribution } \\
\text { facilities and records are verified } \\
\text { - Butchers are monitored every year to guarantee } \\
\text { product origin, authenticity of supply and product } \\
\text { identification at point of sale }\end{array}$ \\
\hline $\begin{array}{c}\text { Ternera } \\
\text { Asturiana }\end{array}$ & $\begin{array}{l}\text { - Geographical origin } \\
\text { - } \text { Breed } \\
\text { - } \text { Minimum suckle period } \\
\text { - } \text { Housing conditions } \\
\text { - Maximum age of the animal at slaughter time } \\
\text { - Pre-established conformation and fat cover of carcasses } \\
\text { - Ph value after slaughtering and color of meat } \\
\text { - Labeling and commercialization standards } \\
\text { - Traceability } \\
\text { - Official registers of members: stock farms, slaughterhouses, } \\
\text { cutting plants and wholesale suppliers, managed by the } \\
\text { Council of Ternera Asturiana; membership may be withdrawn } \\
\text { for non-compliance }\end{array}$ & $\begin{array}{l}\text { - Identification of calves at farms by means of an ear } \\
\text { - } \text { Iag and an information sheet } \\
\text { - Classification of carcasses } \\
\text { - Checking of data and documentation before } \\
\text { certifying each carcass } \\
\text { - Microbiological analyses } \\
\text { - Labeling of cuts } \\
\text { - Inspection of cold storage rooms, quartering houses } \\
\text { - Cond retailers }\end{array}$ \\
\hline
\end{tabular}


TABLE 4

\section{Quality Control Mechanisms in Private Trademarks}

\begin{tabular}{|c|c|c|c|}
\hline Trademark & Specifications and selection of partners & In-house controls & Inter-firm controls \\
\hline BonÁrea & $\begin{array}{l}\text { - Production and provision of fertilizers and plant } \\
\text { health products to fodder producers } \\
\text { - Technical assistance in building and farm } \\
\text { performance } \\
\text { - Internal specifications } \\
\text { - Controlled supply of feed } \\
\text { - Training for cooperative members } \\
\text { - Technical veterinary support } \\
\text { - Traceability }\end{array}$ & 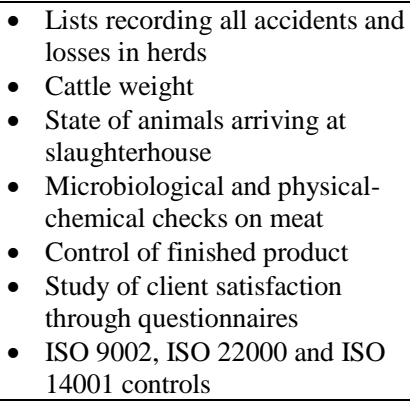 & $\begin{array}{l}\text { - Control of external } \\
\text { supply sources (of little } \\
\text { significance because of } \\
\text { the almost complete } \\
\text { vertical integration) }\end{array}$ \\
\hline$F Q C$ & $\begin{array}{l}\text { - Mixed breeds (no dairy breeds and no young } \\
\text { bulls) and animal origin } \\
\text { - Written and formalized list of specifications for } \\
\text { beef production and slaughtering firms (includes } \\
\text { maturation time) } \\
\text { - Formalization of written tripartite contracts } \\
\text { between Carrefour, a specific slaughtering firm } \\
\text { and a producer's association } \\
\text { - Formalization of control planning } \\
\text { - Traceability } \\
\text { - Registration of authorized feed manufacturers and } \\
\text { cattle dealers } \\
\text { - Accreditation by an audit - before the start of the } \\
\text { business relationship - for slaughterhouses, } \\
\text { producers associations, cattle dealers and feed } \\
\text { firms }\end{array}$ & - Control at supermarkets & $\begin{array}{l}\text { Periodic audits of feed } \\
\text { firms, local producers' } \\
\text { groups, dealers and } \\
\text { slaughterhouses } \\
\text { - Quality controls at the } \\
\text { farm level (private } \\
\text { cattle dealers) } \\
\text { - Logbook at the farm } \\
\text { level } \\
\text { Control of meat } \\
\text { shipped from } \\
\text { slaughterhouses }\end{array}$ \\
\hline
\end{tabular}




\section{APPENDIX}

\section{INTERVIEW PROTOCOL}

\begin{tabular}{|l|ll|}
\hline Introduction & $\bullet$ & Explain context of the research \\
\hline The Quality Signal & $\begin{array}{l}\text { Characteristics (nature and attributes) } \\
\text { Economic performance (market, price and consumption } \\
\text { evolution; sales and price evolution of goods sold under the } \\
\text { signal; goodwill of the quality signal) }\end{array}$ \\
\hline Agents, Technology & $\begin{array}{l}\text { Agents involved in production and control (description of the } \\
\text { different levels of the supply chain (producers / processors / } \\
\text { and Transactions }\end{array}$ & $\begin{array}{l}\text { retailers; organization of agents) } \\
\text { Description of the production process }\end{array}$ \\
& $\begin{array}{l}\text { Transactions in the supply chain (between producers and } \\
\text { processors; between processors and retailers) } \\
\text { Quality control in the supply chain }\end{array}$ \\
\hline Coordination in the & $\begin{array}{l}\text { Contractual relations (between owner(s) of the quality signal } \\
\text { and his suppliers/retailers; between users of a common quality } \\
\text { supply Chain }\end{array}$ & $\begin{array}{l}\text { signal) } \\
\text { Beyond contracts: governance structures (governance of the } \\
\text { "transactions chain" between owner(s) of the signal and } \\
\text { suppliers/retailers; governance of the quality signal use) }\end{array}$ \\
\hline
\end{tabular}

